\title{
DESMANCHAR O CINEMA: VARIAÇÕES DO FORA-DE-CAMPO EM FILMES INDÍGENAS ${ }^{1}$
}

Em comentário a seu filme A iniciação do jovem xavante (I 999), apresentado no curso Pensamento, cinema e política xavante, ${ }^{2}$ o cineasta Divino Tserewahú contou estar trabalhando em novas filmagens que só poderão ser vistas pelo público waradzu (não indígena) em alguns anos. Segundo ele, essas refilmagens participam de um processo maior que consiste em "desmanchar" para refazer todos os seus filmes. Tal processo estaria associado a seu próprio amadurecimento, fruto de uma relação mais estreita com o pensamento e o olhar dos anciãos da aldeia.

Quando os anciãos aprovaram o corte final [do filme A iniciação do jovem xavante], foi um sucesso. O lançamento na aldeia foi muito lindo. Mas isso foi no começo. Depois foi mudando a ideia deles e eu comecei a "apanhar" [levar broncas] de novo: 'Está curto! Esse era bom, mas você cortou. Cadê?'

Na última aula do curso, Tserewahú nos mostrou um corte do filme que está realizando sobre o ritual de iniciação e progressão no mundo do wai'a, o mundo espiritual-xamânico do homem xavante, I5 anos depois da produção de seu filme Wai'a Rini: o poder do sonho (200I). O trabalho que assistiríamos, segundo o cineasta, era cinema indígena "verdadeiro" (uptabi, "registrado em cartório"): “cinema que nós produzimos para o nosso povo, sem legendas. Uma versão longa [na] qual eles podem ver tudo". No filme, as falas não são traduzidas para o português, e os planos, em sua maioria, mantêm uma intrincada 
relação com a duração dos eventos rituais; a montagem segue o movimento cíclico e reiterativo das performances corporais e sonoras.

Deixamos a sessão desse filme-em-processo tomados pela beleza das imagens. César Guimarães, um dos professores parceiros do curso, comentou que talvez fosse esse o sentido de se "desmanchar" um filme (tal como Tserewahú enunciara): refazê-lo, distendê-lo, alongar seus planos, abrir o filme a suas relações com o fora - sejam elas com a comunidade, os anciãos; sejam com os animais e potências espirituais da floresta, das caçadas e dos sonhos.

Divino Tserewahú nos disse também que, cada vez mais, se esforça em fazer as imagens de acordo com um "olhar indígena", sempre múltiplo: "olhares dos anciãos, olhares das mulheres, tenho que aceitar tudo. Então eu junto. Por isso é que eu faço quatro trabalhos na montagem". ${ }^{3}$ O que parece estar em jogo é precisamente seu caráter compartilhado, negociado, marcado por idas e vindas das imagens - constantemente feitas, desfeitas e refeitas, abertas e fendidas pelos processos compartilhados de sua gênese e de sua circulação.

\section{O CINEMA E AS FORÇAS DO FORA}

Sem desconsiderar experiências pontuais anteriores, ${ }^{4}$ pode-se dizer que a produção de cinema por realizadores e coletivos indígenas no Brasil ganha uma trajetória sistemática com o trabalho do Vídeo nas Aldeias, projeto iniciado em 1986 no contexto de um indigenismo alternativo à atuação do Estado. Desde então, o VNA tem desenvolvido projetos de experimentação, formação e produção audiovisual ancorados em uma perspectiva de diálogo intercultural, de compromisso e militância.

No momento em que escrevemos este artigo, nos deparamos com um contexto de produção profícua e estimulante, que se torna, ao mesmo tempo, motivo de dificuldade: de um lado, finalmente parece reconhecida a relevância do trabalho do Vídeo nas Aldeias, arduamente encampado por Vincent Carelli e suas alianças (reconhecimento que, diga-se de passagem, não resulta necessariamente na garantia dos recursos materiais e financeiros que um projeto dessa importância merece e necessita). ${ }^{5}$ O trabalho de formação do VNA tem contribuído para ampliar significativamente a produção dos coletivos indígenas de cinema, permitindo, em alguns casos, a consolidação de verdadeiras cinematografias. Alguns desses grupos vêm adquirindo cada vez mais autonomia para produzir seus filmes, conquistando espaços de circulação em festivais e mostras no país e afora.

Mais recentemente, essa produção de cinema tem-se multiplicado para além da atuação do Vídeo nas Aldeias. ${ }^{6}$ Filmes-rituais, ficções roteirizadas e encenadas a partir de narrativas míticas, documentários de caráter militante e pedagógico; testemunhos, registros urgentes em situações de risco: todas essas imagens compõem uma produção difusa e heterogênea que contribui para a afirmação da experiência histórica e cultural dos povos indígenas no 
Brasil. De modo mais ou menos sistemático, o cinema tem participado da trajetória de luta por autonomia de grupos em situações as mais distintas: daqueles que tiveram suas terras demarcadas (e que retomam práticas e rituais outrora abandonados) àqueles que se valem das imagens para fazer ver o contexto terrível de ameaças e de violência ao qual estão submetidos e contra o qual resistem. Em tantos casos, o cinema funciona como uma espécie de catalisador para a experiência de grupos que se esforçam por reconquistar seu "devir-índio".?

Não raro a categoria do cinema indígena (ou afins como cinema nativo, cinema dos povos originários ou autóctones etc.) é alvo de crítica, que se endereça a um ou outro termo da equação. De um lado, a rubrica reiteraria a abstração do "indígena" - algo que a etnografia tem trabalhado por desfazer. De outro, sugere certa idealização desse cinema que se tem mostrado de fato impuro, cruzado, realizado em meio a processos de formação e criação compartilhada entre índios e não índios; a partir de técnicas, tecnologias e poéticas de tradição visual ocidental. Não sem razão, Paula Morgado e Nadja Marin (20I6) questionam a abordagem dessa prática sob a forma de uma especialidade, já que o jovem indígena "mediador cultural" muitas vezes assume o cinema como prática temporária ("eu estou cineasta") e não como atividade estética ou profissionalmente circunscrita ("eu sou cineasta").

Por um lado, uma abordagem endereçada exclusivamente ao cinema como prática especializada, alijada dos processos mais amplos de socialidade e de mediações dos quais participa, perderia o que há ali de mais rico, seu viés indissociavelmente histórico, cultural, político e performativo. Por outro, tampouco podemos desconsiderar a força que essa prática exerce na vida dos próprios cineastas em suas várias relações. Em um comentário ${ }^{8}$ a filme Wai'a Rini (200I), Divino Tserewahú enfatizou o modo como sua vida está investida pela prática cinematográfica.

Se eu não trabalhar, se eu não tiver material para fazer [filmes], eu não durmo bem. Fico pensando sem parar. Minha vida virou assim. Porque os velhos se animam muito com o que filmo, edito e mostro ao público da aldeia. Não é fechado, é aberto. Eu coloco o telão sob as mangueiras no pátio central [warã].

Um filme nos interessa assim não só em seus aspectos simbólicos ou formais, mas principalmente em sua dimensão pragmática, exigindo ênfase na "agência, intenção, causação, resultado e transformação" (Gell, I998: 6).9 Não é preciso contudo abandonar as questões propriamente expressivas e formais: se elas não visam a uma investigação estritamente estética é porque advêm antes da crença de que, lugar de inscrição precária dos eventos, das ações e da experiência, o cinema seja capaz de cifrar, por meio dessa inscrição, processos que o ultrapassam. Mais do que isso, acreditamos que ele abrigue, em suas estratégias de linguagem e em sua formalização - a composição do 
plano, a mise-en-scène, a montagem - pragmáticas mais amplas. Dito de outro modo, um filme - e isso nos parece definidor da produção de cinema por coletivos indígenas - se constitui por suas relações com o fora. Um filme se fortalece nas forças que atuam de fora para possibilitá-lo, mas também para desfazê-lo (ou, nas palavras de Tserewahú, para “desmanchá-lo").

\section{O CORPO-CÂMERA E SUAS RESSONÂNCIAS}

De início, o corpo; corpo-câmera. Em artigos pioneiros, Ruben Caixeta de Queiroz (I998, 2004, 2008) desenvolveu um argumento que vincula o cinema realizado por cineastas e coletivos indígenas ao pensamento de Lévi-Strauss ao defender que, se esses podem ser considerados filmes indígenas, é porque são marcados ontologicamente por um "pensamento selvagem", já que depositam "nos corpos um lugar central para a constituição de sua socialidade" (Caixeta de Queiroz, 2008: I I7-I I8). Como bricolage, prática heteróclita, na qual o corpo ganha centralidade, o cinema (especialmente o documentário) ofereceria aos indígenas um meio produtivo para realizar sua antropologia reversa, nativa.

Nos termos do cinema, essa centralidade do corpo teria como desdobramento direto o privilégio ao momento da filmagem em relação às operações de montagem. ${ }^{\text {10 }}$ Mais do que uma assimilação de códigos prévios, filmar (assim como o aprendizado técnico de manejo da câmera) envolve um saber corporal, ${ }^{I I}$ em mútua reconfiguração entre corpo e máquina. Bastante diversos, tanto na maneira como o corpo é convocado quanto em seus efeitos expressivos, os filmes guardam em comum o fato de que, acoplado à câmera, o corpo do cineasta não se furta nem se protege do atrito com o mundo. Trata-se de um corpo que, ao filmar, marca sua presença em cena, deixando-se, por sua vez, afetar por aquilo que filma. A imagem é o índice de uma relação mediada pela câmara. Em maior ou menor grau, essa câmera-artefato-corporal - câmera-máscara, câmera-pele-de-animal, câmera-flecha, câmera-canoa, câmera-armadilha, câmera-flauta, câmera-bicho-preguiça (Brasil, 20I3) - é incorporada às práticas ritualísticas e cotidianas nas aldeias.

Inicialmente o acoplamento entre o corpo e a câmera permite que a dimensão que denominaríamos fenomenológica - ou seja, tudo aquilo que se inscreve concretamente na imagem, em sua gênese "indicial" ${ }^{2}$ - entre em relação com uma outra dimensão, digamos, cosmológica - constituída por processos muitas vezes invisíveis que afetam a imagem, mas que a ultrapassam. Assim como em situações de xamanismo e ritual o corpo é afetado por agências cuja presença não nos é dado ver, também a câmera o será: o que ela apreende e inscreve será efeito da relação não apenas com os objetos e fenômenos visíveis, mas também com essas agências invisíveis. O corpo-câmera estabelece vínculos, contiguidades e vizinhanças entre as dimensões visível e invisível, uma a ressoar a outra: e o que se inscreve na imagem constitui, assim, relações. ${ }^{13}$ 
Acreditamos que essa convocação do corpo - corpo-câmera situado e relacional - repercuta e constitua também outros processos de construção do filme. Também a montagem ganhará tantas vezes o aspecto de uma busca, marcando-se como processo tateante, e em alguns filmes os corpos serão convocados de maneira concreta, literal, no momento de manejo das imagens na ilha de edição. ${ }^{14}$ Um filme já finalizado poderá ser refeito, repercutir em outros filmes ou mesmo ser "desmanchado", como nos sugeria Divino Tserewahú. ${ }^{15}$ Imagens de arquivo serão retomadas para provocar reencenações por parte daqueles que atualizam a experiência histórica por meio dos seus gestos, corpos e lembranças. ${ }^{16}$ Mesmo a situação de exibição das imagens será, em muitos casos, trazida para o interior da cena em circunstanciais "comunidades de cinema": expõem-se ali os corpos dos espectadores, sua reação sensível às imagens - as palavras, as interjeições, os olhares atentos (Brasil, 20I6a). Poderíamos dizer então que, por meio desses e de outros procedimentos, os filmes trazem para a filmagem atividades que a precederiam, como a montagem e a exibição. Expostas em cena nos filmes, essas etapas estão assim reincorporadas, e o cinema se explicita como uma pragmática na qual o corpo e as máquinas estarão de um modo ou de outro implicados. O cinema se acopla a outras atividades, adquirindo um pouco de seu movimento e duração: a dança, a conversação, a caminhada, a caçada, a pescaria, a construção da casa, o manejo de um artefato.

É preciso dizer, em contrapartida, que os filmes não deixam de instaurar uma espécie de defasagem (definidora, afinal, do cinema): implicado, o corpo-câmera não o faz sem tomar distância (parcial, nunca demasiada) em relação àquilo que filma, tornando a experiência objeto de reflexão e de perspectivação. ${ }^{17}$

Feitas essas proposições, deixemos de lado as tentativas de definição a priori do que seja o cinema indígena - já que suas formas de existência variam: dos registros quase sem montagem exibidos nas aldeias aos filmes de arquivo de montagem enfática; das tomadas urgentes em situações de confronto aos filmes-rituais que, em alguns casos, se tornam espécies de "metarrituais" (Caixeta de Queiroz, 2008); dos filmes montados em parceria com editores não indígenas aos novos trabalhos montados exclusivamente por realizadores indígenas, produção essa ainda incipiente. Neste momento, atentaremos a filmes em que forças e agências externas ao mundo visível atravessam e tensionam a forma dos filmes, distendendo-a (sob o risco de, às vezes, desmanchá-la); forças e agências do fora - em termos fílmicos, do fora-de-campo. ${ }^{18}$ Invisíveis, elas se modulam, precipitam e inscrevem nas imagens, de modo variável e singular de filme a filme. Talvez (e essa é apenas uma hipótese) possam nos sugerir relações entre os filmes, em sua formalização singular, e processos cosmológicos mais amplos. Mas, se esses processos deixam sua marca na imagem, essas tendem a ser sempre oblíquas, enviesadas, nunca plenas ou diretamente apreensíveis. 
Sem desconsiderar a dimensão fenomenológica definidora do cinema, vamos arriscar então a hipótese de que nele se engendra também uma máquina cosmológica, cuja matéria é em grande medida (mas não apenas) invisível: as propriedades espaciais e temporais do universo, os tipos de seres que nele se encontram, os princípios ou potências que regulam e animam sua origem, que atravessam sua experiência histórica e seu devir (Viveiros de Castro, I99I). Em termos fílmicos, a forma como essas duas máquinas, fenomenológica e cosmológica, se relacionam traduz-se de forma indireta, não mimética, pela relação entre o campo e o fora-de-campo - aqui definido simplesmente como aquilo que não está visível em cena, mas que nela incide. Em sua dimensão cosmológica, o fora-de-campo será um lugar contíguo à aldeia, abrigando contudo mundos outros, arriscados, habitados por animais-espíritos, por agências e potências não humanas da floresta. Como uma espécie de expressão cinematográfica que articula domínios análogos àqueles em questão no "multinaturalismo" ameríndio (Viveiros de Castro, 2002), o fora-de-campo será justamente o que torna permeável, o que permite a passagem, no filme, entre mundos contíguos mas profundamente díspares, incomensuráveis.

Essa hipótese, ainda excessivamente abstrata e generalizante, pode ganhar a forma de perguntas cujas respostas se darão à escala dos filmes: Como campo e fora-de-campo se relacionam em cada caso? Como se passa de um a outro e o que se produz nessa passagem?

\section{CURADORES DA TERRA-FLORESTA: VER, SER VISTO}

Comecemos retomando essa estratégia simples, mas de efeitos complexos, reversos: em Urihi Haromatimape: Curadores da terra-floresta (2013), o diretor Morzaniel Iramari Yanomami recorre a planos longos, no quais os corpos são filmados lateralmente, mantendo sua relação com o espaço vazio em torno. Uma a uma, o filme acompanha as performances de xamãs yanomamis (dos mais experientes aos iniciantes), que se reuniram na aldeia de Watoriki por iniciativa de Davi Kopenawa. ${ }^{\text {I9 }}$

Desde o início, o filme explicita sua destinação, convocando os espectadores napë (não indígenas) a aprender sobre as práticas e o pensamento xamânicos. Na introdução do filme, vemos a fabricação do yakoana, pó cuja inalação permite aos xamãs receber a visita dos xapiripë (como os Yanomami denominam a miríade de povos-espíritos com os quais se relacionam, se aliam e não cessam de aprender). Acompanhamos a chegada dos convidados, vindos de aldeias vizinhas, a cuidadosa pintura e ornamentação dos corpos. Ouvimos a narração em voz over a nos ensinar sobre o trabalho dos pajés que cuidam do mundo para não deixá-lo "ficar triste e chorando". A partir daí, a câmera segue, uma a uma, as performances abrigadas no amplo pátio ao centro da aldeia: em certas tomadas, ela assume o ponto de vista dos demais xamãs, que assistem às performances, alinhados em semicírculo; mas na maioria das vezes, 
ela filma lateralmente, apanhando a relação entre aqueles que assistem, aqueles que performam e o entorno.

A filmagem não encobre nem afasta as impurezas do plano - as hesitações e leves oscilações que caracterizam a busca do enquadramento preciso, econômico. Ao variar entre planos mais fechados, atentos à minúcia dos gestos, e planos abertos que reinserem os corpos no espaço, Morzaniel estabelece relações entre as dimensões do visível e do invisível, tornando o plano permeável. Partindo então de um olhar fortemente fenomenológico, aberto à integridade das performances ritualísticas em sua própria duração, Curadores da terra-floresta se abre e se desdobra, constituindo-se assim por um trabalho com o invisível: em vários planos, o espaço vazio dura e atua em contiguidade com o fora-de-campo (ver foto I, na p.608). Nesse sentido, o filme - essa é a hipótese que tentamos sugerir - altera a experiência com a imagem, de modo que ela possa abrigar não apenas o que se dá a ver, mas também o que nela só se perceberia, quem sabe, por meio de uma outra modalidade de visão.

Morzaniel filma um encontro de xamãs, espécie de "parlamento" (que abriga homens e espíritos animais), realizando outra parte da tarefa "cosmopolítica": ${ }^{20}$ aquela que se endereça a nós, os napë, para que vejamos e aprendamos sobre essa importante atividade dos xamãs. Mais do que decupar os gestos, em uma narrativa explicativa, Curadores toma os corpos no espaço, enfatiza a ligação entre as performances e o entorno do pátio, da floresta e da montanha, de onde descem os xapiripë, em espelhos resplandecentes, para cantar e dançar com os xamãs (Kopenawa \& Albert, 20I5). Trata-se de preservar a contiguidade entre o espaço fenomenológico do filme e o espaço cosmológico, filmando a relação entre um e outro; o modo como um age sobre o outro, como um reverbera no outro, ainda que permaneçam ontologicamente descontínuos um em relação ao outro.

O plano centrífugo, aberto ao que vem de fora - do fora-de-campo, justamente - produz uma relação indicial por meio da qual o visível é atravessado pelo invisível, sendo por ele afetado e alterado. Por meio dos cantos entoados pelos xamãs, os xapiripë - invisíveis ao nosso olhar - parecem povoar o espaço, atravessando o corpo em sua transformação. Se nós não "vemos" imagens dos espíritos (imagens-espírito), podemos contudo vê-las agindo sobre o corpo do xamã. É peculiar aqui o funcionamento do índice: "como espectadores somos convocados não a crer naquilo que nossos olhos veem, e sim naquilo que os olhos não veem, mas que ainda assim age sobre o corpo em performance" (Brasil, 20I6c). O invisível atravessa os corpos, como o vento atravessa a vela de um barco, tornando-se concreto em sua invisibilidade e conferindo à vela e ao barco algo de sua agência.

A montagem paradigmática, em séries de performances, ganha pertinência: trata-se menos de decupar a atividade do xamã, para dali deduzir a narrativa de seu entendimento, do que de colocar lado a lado performances singu- 

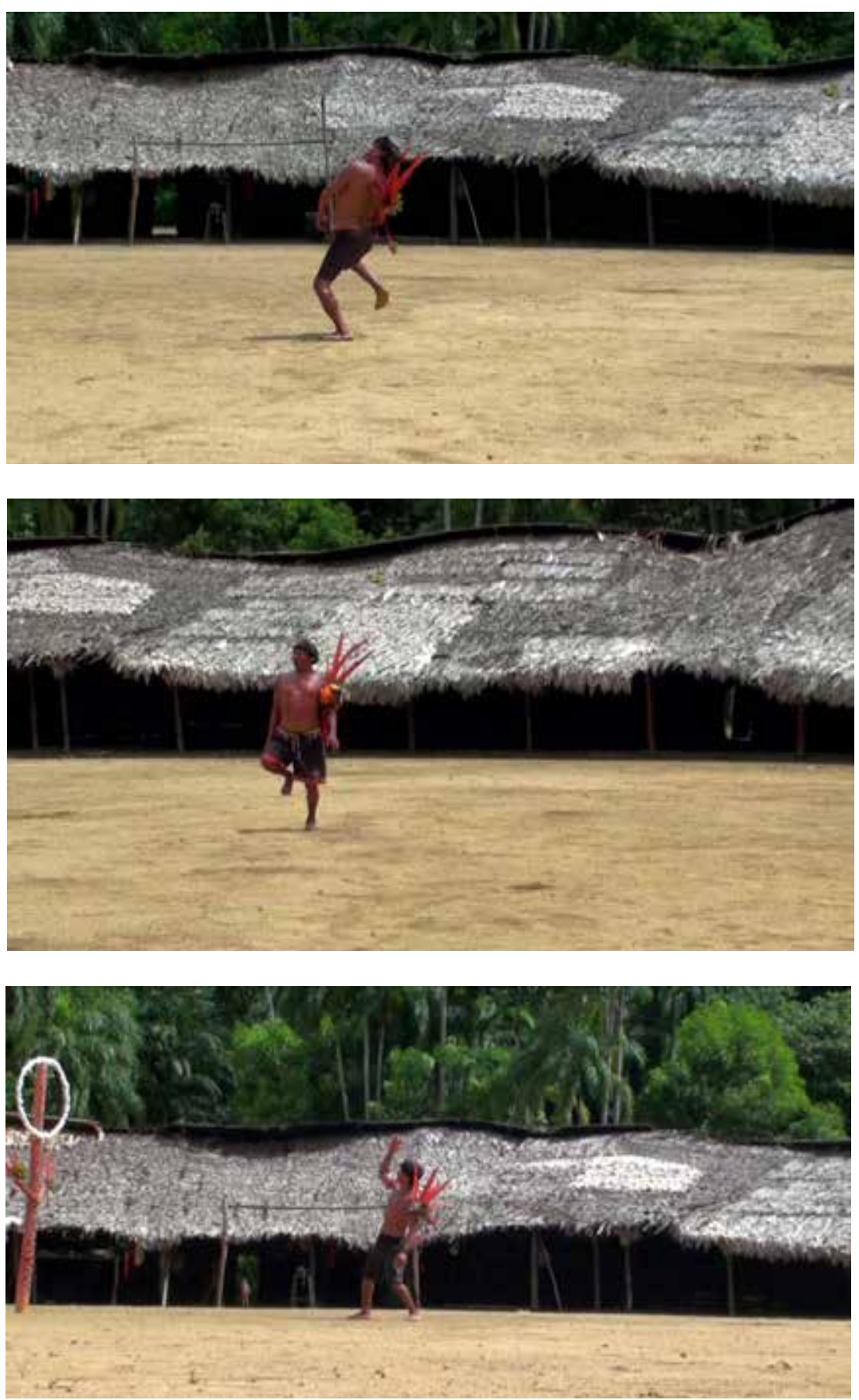

I

A performance e o pátio vazio

Fonte: Fotogramas do filme Curadores da terra-floresta 
lares: cada corpo a entoar um canto e a percorrer o pátio em devir-animal; cada corpo, uma manerie, um modo de acionar um mundo e os seres que o habitam. A série permite acessar paradigmaticamente aquilo que atravessa, em suas variações, cada performance; acessar, portanto, o dispositivo transversal do xamanismo. Ela nos ensina também como esse dispositivo não se deve abstrair do corpo, produzindo-se nessa relação entre a performance singular sua manifestação visível, situada - e os espaços que atravessa.

Operando passagens entre o visível e o invisível, o filme ressoa algo do xamanismo, assumindo a tarefa de ensinar aos espectadores brancos a ver aquilo que não veem. Ou, mais concretamente, ver o que os xamãs, reunidos em círculo, estariam vendo enquanto apontam para o fora-de-campo (ver foto abaixo). Se não temos a capacidade de ver do mesmo modo - afinal, não dominamos as técnicas xamanísticas e não fomos formados nessa outra modalidade de visão -, resta-nos imaginar. Em certo sentido, o filme participa dessa pedagogia em que ensinar a ver significa reaprender a imaginar, ou, nos termos de Kopenawa \& Albert (20I5), a sonhar.

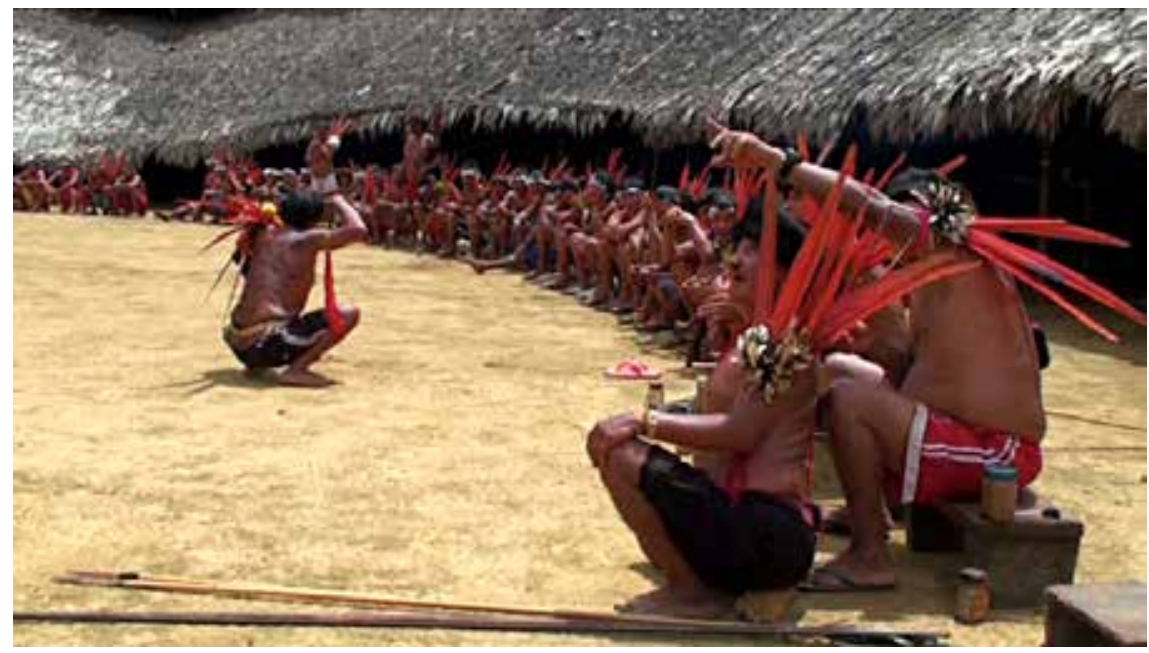

2

Enquadramento lateral: miradas de xamãs

Fonte: Fotograma do filme Curadores da terra-floresta 
Nesse sentido, o filme parece ancorar-se em tradição escópica distinta daquela ocidental (da qual o cinema participa, não sem a alterar). O que Morzaniel filma são "imagens-espírito": na cosmologia yanomami, os xamãs não apenas veem os espíritos, mas são vistos por eles, para então ver através de seus olhos (Kopenawa \& Albert, 20I5). ${ }^{21}$ Não seria esse, em suma, o tipo de convocação que o filme faz a nós, espectadores? Olhamos a imagem - as maneiras dos corpos e os vazios do pátio - e nos sentimos também olhados por ela. O invisível parece então ser capaz de nos olhar em retorno; em certo sentido, de nos interpelar. Tomado como dispositivo estritamente fenomenológico, o cinema não pode ver, nem nos fazer ver os espíritos. Mas, tendo sua fenomenologia alargada, ou mesmo invertida pela cosmologia (as modalidades de visão que ela propõe), trata-se menos de ver o invisível do que de ver "por meio" do invisível.

\section{AS HIPERMULHERES: RESSOAR}

A sua maneira, o filme As hipermulheres (20I I) também sugere uma pedagogia da visão que nos ensina a perceber as agências que, invisíveis, incidem no mundo visível. Se em Curadores, o yakoana é uma espécie de alimento para os espíritos - como se o sopro do pó através da taquara fizesse a ligação entre o mundo dos Yanomami e aquele dos xapiripë -, aqui, a relação entre um e outro se dá em uma espécie de ressonância, que encontra nos cantos e na dança seu elemento de passagem.

A direção do filme é assinada pelo realizador indígena Takumã Kuikuro, pelo antropólogo Carlos Fausto e por Leonardo Sette, do projeto Vídeo nas Aldeias. ${ }^{22}$ Assim como os filmes anteriores, As hipermulheres está intimamente ligado ao ritual que põe em cena, principalmente no que se refere a seus aspectos sensíveis. O documentário apresenta a aldeia de Ipatse em meio aos preparativos para o grande ritual feminino do Alto Xingu, o Jamugikumalu (na língua kuikuro). Nesse ritual, o mundo das mulheres xinguanas é posto em relação com um outro mundo, o mundo das mulheres-itseke, das "hiperchefas" - iamurikumã, na língua aruak - míticas. Isso porque esse ritual, assim como outros rituais unduhe dos Kuikuro, pode ser tüitsekekinhü (Mehinaku, 20го) fazer relação com itseke. ${ }^{23}$ Se o mito narrado no filme pelos mestres das histórias já dava a perceber uma relação estreita entre as performances rituais e as performances das mulheres-itseke míticas, é por um comentário feito por um dos espectadores do ritual assentado à sombra da Kuakutu²4 que se confirma algo que podíamos intuir: "Itseke! Do mesmo jeito que as hipermulheres se pintaram. Olhe lá, itseke. É itseke de verdade!”.

Adornadas com suas pinturas, colares, cintos, joelheiras, braçadeiras e cocares, percutindo seus pés e balançando seus braços, cantando e dançando os cantos que as mulheres míticas cantaram e dançaram para se transformar em itseke, as mulheres filmadas pelas cinegrafias kuikuro no ritual estabele- 
cem um campo de ressonâncias entre diferentes domínios. A relação da câmera com a mise-en-scène das mulheres sugere que o filme encontra-se apanhado pelo campo de ressonância maquinado no ritual (Belisário, 20I4a; 20I6a). O campo de visibilidade que o filme constitui junto a essas mulheres está em ressonância com o fora-de-campo invisível das itseke - com quem dançam e cantam, para quem oferecem o alimento e o discurso cerimonial. Os cantos, as coreografias e as pinturas das jamugikumalu ressoam no corpo das mulheres e do próprio filme, dando materialidade e forma à transformação mítica (virtual) das mulheres em itseke. Nessas sequências rituais, o invisível se faz presente por meio da ressonância com o visível, campo e fora-de-campo vibram uma mesma frequência maquinada pelo ritual mítico.

A sequência do grande círculo coreográfico interétnico (Sahugagülü) é um bom exemplo de como esse fenômeno da ressonância estabelece relações entre o campo visível e aquilo que subsiste invisível no fora-de-campo. Quando a câmera se desloca do polo visual - as jovens que encabeçam a fila - para o polo musical dessa forma coreográfica (ver foto 3, na p.6r2), o filme faz ressoar em sua escritura uma componente de extrema intensidade: os cantos das igisüoto que, ao tomar o espaço sonoro da cena, lançam a câmera e seu microfone novamente ao movimento em ressonância com a grande forma coreográfica.

O ritual se faz perceber no filme como um grande ressoador a colocar em relação os corpos visíveis e audíveis das mulheres no pátio cerimonial da aldeia com os corpos invisíveis e imemoriais das itseke no fora-de-campo. Ao traçar seu enquadramento (corte móvel no contínuo espacial) em ressonância com a coreografia transformacional das mulheres-itseke em cena, a câmera de Takumã e de seus colegas do Coletivo Kuikuro de Cinema constitui, para o espectador do filme, um espaço cujos aspectos sensíveis modulam as direções, as intensidades e afecções implicadas nesse devir-ritual.

Nas cenas de xamanismo, tanto em As hipermulheres quanto nos filmes anteriores de Takumã, o que se percebe é a presença de uma zona invisível de virtualidades que modifica o estado, as ações e os movimentos dos corpos em campo. Isso porque sua invisibilidade não é só uma operação do enquadramento. Tal invisibilidade no fora-de-campo parece estar muito próxima da noção (e da experiência) da "floresta". A floresta, que circunda a aldeia, por sua vez, pode ser pensada como o seu fora-de-campo, que não cessa de avançar sobre o "campo". ${ }^{25}$ As onças e os itseke partilhariam dessa mesma invisibilidade dos predadores. Ainda que possamos pensar a floresta como um conjunto mais extenso, que engloba a aldeia em uma espécie de continuidade fenomenológica, é a sua dimensão de virtualidade que parece estar em questão quando a onça ou o itseke agem invisivelmente no território dos homens. O ritual faz ressoar no filme essas diferentes dimensões dos itseke. 

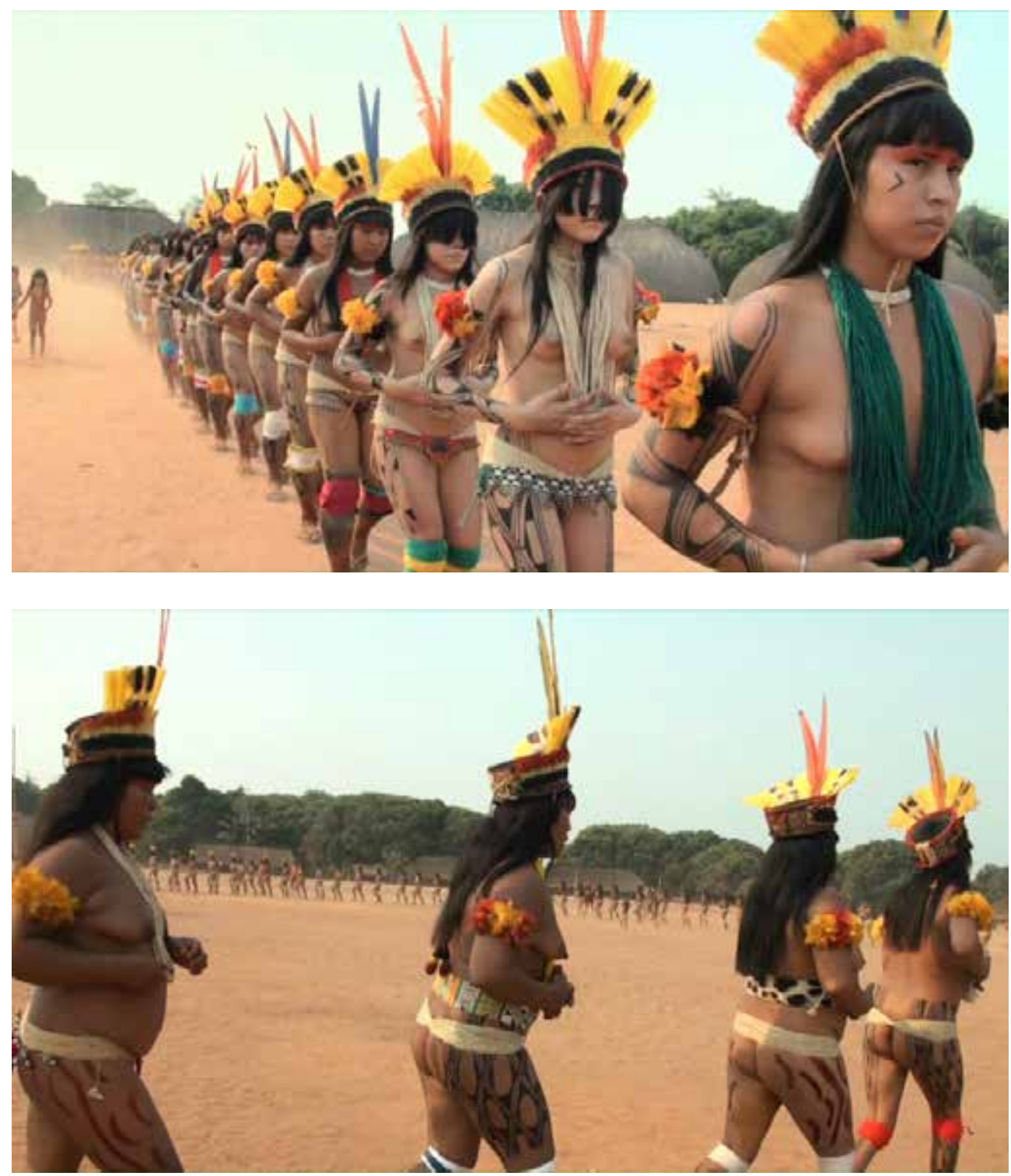


\section{TATAKOX DA VILA NOVA: POVOAR, ESCAVAR}

No documentário Tatakox da Vila Nova (2009), assim como em grande parte dos filmes-rituais dos Tikmũ'ũn (Maxakali), o invisível se faz perceber por um tipo de povoamento da imagem. A singularidade desse filme no cinema maxakali se dá pela figuração que produz ao relacionar os domínios do visível e do invisível: a escavação entre o campo da aldeia e fora-de-campo dos povos-espírito tatakox.

O filme foi realizado pela comunidade da aldeia Vila Nova do Pradinho, localizada na Terra Indígena Maxakali, em Minas Gerais. Após a oficina de vídeo realizada nessa comunidade pelo projeto Vídeo nas Aldeias em 2008, Guigui e os demais xamãs do Pradinho, insatisfeitos com o filme Tatakox (2007) realizado por Isael Maxakali, da Aldeia Verde, resolvem realizar o "mesmo" ritual, para que esse também fosse filmado. Segundo comenta em cena um dos xamãs, "antes ninguém sabia de onde os tatakox tiravam as crianças, mas agora nós vimos” (Manuel Damásio).

A primeira das três sequências que compõem o filme é precisamente a cena em que os tatakox desenterram os filhos para levá-los à aldeia. ${ }^{26}$ Os espíritos-lagarta surgem do fora-de-campo zumbindo suas flautas-taquara. Vêm povoar o espaço da cena imantada pelo buraco; passam a circundá-lo como mariposas até que alguns deles se põem a escavá-lo, expandindo sua abertura. Tudo isso sob a assistência dos xamãs e de Guigui, que dirige não só a mise-en-scène dos tatakox como a própria câmera imersa na tensão entre a tomada de distância (necessária para filmar) e a imersão na dinâmica do ritual como uma de suas agências (ver foto 4, na p. 6I4).

A presença e a mise-en-scène dos tatakox conferem certa entropia à cena (Belisário, 20I6b). E mesmo quando a câmera consegue atravessar o campo de intensidade criado pelo enxame dos espíritos-lagarta em direção ao buraco, seu enquadramento é constantemente atravessado, cortado pelo movimento-mariposa dos tatakox. A saturação do espaço sonoro pelo som das flautas-taquara, apitos e assovios confere uma componente de extrema intensidade à dinâmica sensível da cena. A voz e os gestos dos xamãs precisam estar carregados de energia para se fazer ver e ouvir em meio ao enxame. Tudo vibra ao redor do buraco escuro dos tatakox.

A ação de cavar a terra, que ocupa quase toda a extensão da sequência, torna-se também o trabalho de escavação de uma passagem entre os domínios do visível e do invisível. Trabalho, esse, inscrito no interior daquele campo de intensidades que perpassa toda a cena ritual. Cada golpe que os tatakox desferem sobre a terra ressoa como uma descarga da energia que se acumula em torno do buraco. E quanto maior se torna sua abertura, maior a presença dos filhos de tatakox.

Tragada para o interior do ritual, a câmera parece assumir então uma "perspectiva interna", como se olhasse de dentro do espaço mítico-ritualístico. A constatação poderia soar contraditória frente à demonstração dessa cena difusa, aberta e relacional, mas essa talvez não seja exatamente uma contradição 

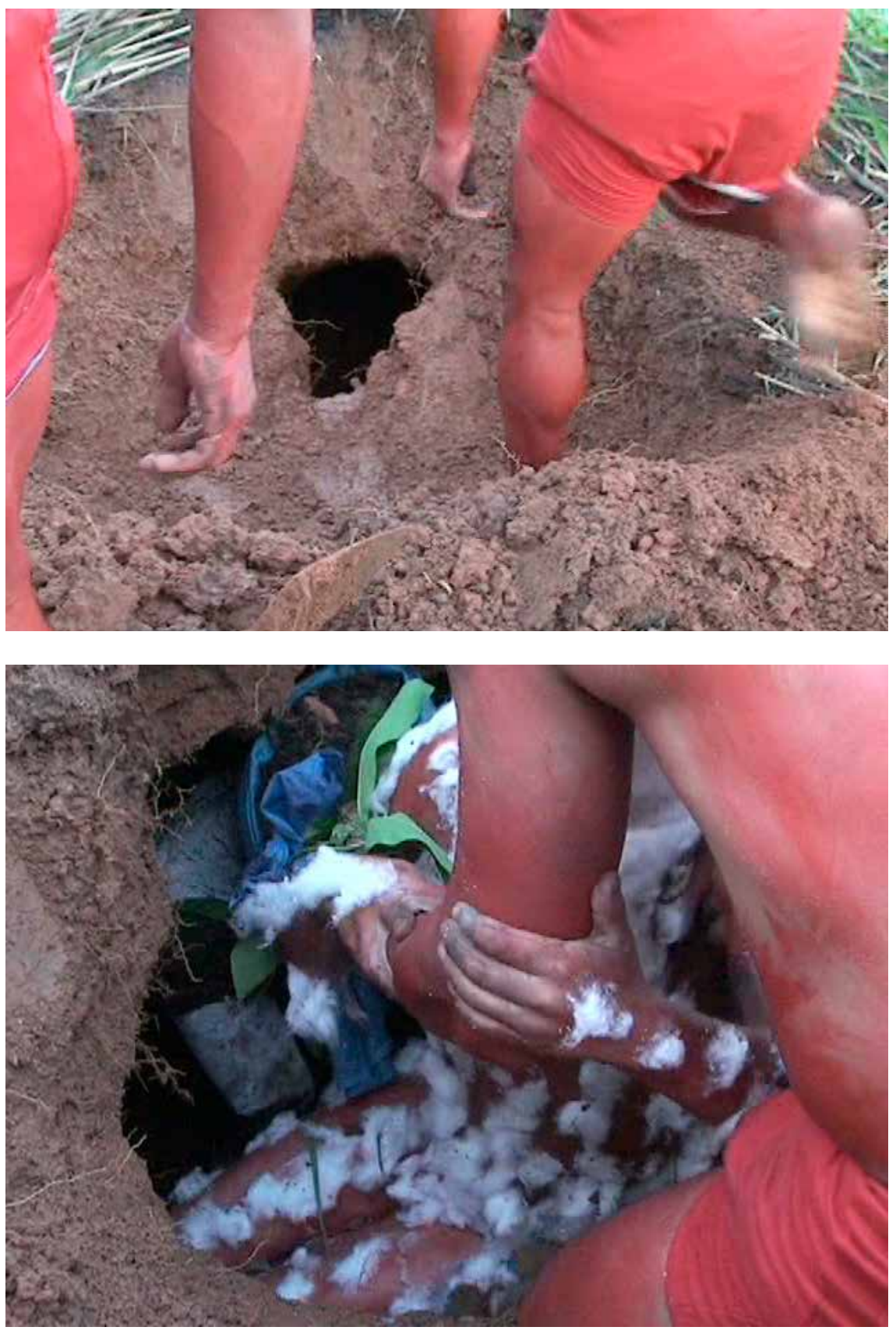
para os Tikmũ'ũn: afinal, entre eles, uma perspectiva interna se define e sobrevive (ou melhor, devém) por força de sua abertura ao exterior (Tugny, 20I I); das relações tão cuidadosas quanto incontáveis que mantêm com os povos-espírito. Por isso, aquilo que nos parece opaco, fechado em sua forma visível (o buraco escuro de onde se retiram as crianças), sob os olhos e as câmeras dos Tikmũ'ũn, abre-se como uma rede de socialidade muito concreta, espécie de "povoamento" do mundo visível por seres, eventos e agências vindos de outros mundos.

Como dissemos, nesse e em outros filmes tikmũ'ũn, ${ }^{27}$ observa-se esse povoamento do espaço da aldeia pelos povos-espírito (os yãmĩyxop) com quem mantêm relações de aliança e mútua adoção. Mais do que simplesmente registrar os eventos, a câmera, reiteramos, parece assumir agência nessas passagens. Não à toa, os cineastas acompanham ou mesmo trazem consigo os visitantes que chegam à aldeia; não raro, a câmera os aguardará ali, na região limítrofe em que o invisível se precipita no plano visível. Os yãmĩyxop povoam o plano que, assim, abrigará a coabitação de espaços descontínuos, mundos incompossíveis. ${ }^{28} \mathrm{Ou}$, ao contrário, os acompanhará em sua despedida da aldeia, e nós os perderemos de vista a desaparecer na mata.

A alteração da máquina "fenomenológica" do cinema pelas forças cosmológicas faz com que se constitua um campo de visibilidade distinto daquele que apontaria para uma objetividade daquilo que é filmado. Pelo contrário, o que está em jogo é precisamente a imagem como experiência, carregada de intensidades e atravessada pelo impensado, por devires-animais. Se o filme pode fazer inscrever algum aspecto da cosmologia dos Tikmũ'ũn, o será menos por um gesto explicativo - que viria organizar e dar sentido ao todo do universo - do que por traços sensíveis das forças e afetos não humanos que lançam os homens (e o próprio cinema) para os limiares do território da significação. Devir-lagarta dos homens, devir-mariposa das lagartas, devir-enxame das taquaras - linhas de fuga que conjuram qualquer possibilidade de unidade de sentido tanto à figura dos espíritos que povoam o cosmo dos Tikmũ'ũn quanto a sua mise-en-scène. Essa outra experiência da visão e da escuta faz emergir um campo de sentidos afetado pelas próprias formas e matérias expressivas: a pintura dos corpos, o seu movimento, o som que emitem. Figurações irredutíveis que fazem inscrever no espaço e na duração da cena outra pragmática da visão. "Não um ato que consiste em projetar sobre o outro corpo uma mirada empírica, o olhar, mas uma experiência relacional, os corpos se deram a ver e as visões foram afetadas mutuamente" (Tugny, 20 I I: 89). E se o corpo do filme pode ser ele mesmo afetado por esse regime de intensidades que arrasta homens e animais a uma estranha zona de vizinhança, é na passagem daquilo que subsistia invisível no fora-de-campo ao domínio do visível que essas intensidades cosmológicas ganham uma potência arrebatadora. E à medida que nós, os "não índios", somos convocados a habitar esse outro território da experiência como espectadores do filme, é o próprio cinema que devém outro. 


\section{SHUKU SHUKUWE: TROCAR DE CASCA}

A maneira como Shuku Shukuwe: a vida é para sempre (20I2) faz relacionar o visível e o invisível nos parece outra: trata-se menos de ver o invisível contíguo, a incidir indicialmente no mundo visível, do que de ver aquilo que, já presente (de certo modo, visível) em cena, se faz notar por uma leve oscilação entre figura e fundo. O filme faz parte do projeto Huna Hiwea, o livro vivo, organizado por Agostinho Manduca Mateus Ika Muru, ${ }^{29}$ e reencena mitos huni kuĩ (kaxinawá), nos levando à origem das ervas medicinais. Organizado em quadros relativamente autônomos, cada qual dedicando-se a um aspecto do repertório mítico huni kuĩ, Shuku Shukuwe constitui-se por planos centrípetos que circunscrevem, com ênfase, os elementos e eventos em cena (algo, portanto, diametralmente oposto aos planos centrífugos e entrópicos de Tatakox). Carolina Canguçu (2016), pesquisadora que também participou da produção do filme, aproxima Shuku Shukuwe ao cinema de poesia para constatar que ali não se enfatiza o fora-de-campo: o enquadramento estático teria a força de trazer os acontecimentos para o interior da cena delimitada pelas bordas do quadro. Diante dessa opção formal, nos perguntamos então: como - por meio de que operações - a dimensão cosmológica e mítica atua no filme, incidindo em seu campo visível?

Já em seu início, Shuku Shukuwe estabelece os traços definidores de sua composição: o plano fixo, a duração da imagem, a presença dos corpos, dos eventos, dos sons e das vozes, que não estão a serviço da atuação dos atores no decurso da narrativa, mas que se afirmam em sua "expressão sensível" (Canguçu, 20I6). Os mitos não se traduzem por meio de uma encenação naturalista: ao contrário, a composição da cena, assim como a performance dos atores, não recusa sua condição de artifício, produzido pelo e para o filme. Pajé Agostinho é personagem e narrador em cena e, para a tarefa, recorrerá fundamentalmente ao canto.

Uma cena de Shuku Shukuwe em que o canto do mito de origem é entoado nos oferece, de início, as pistas acerca do modo muito particular como o fora-de-campo se dá a ver; o modo como se revela ou infiltra-se no campo visível. Trata-se de um momento central - irradiador -, no qual, em um único e longo plano, pajé Agostinho e Dua Busẽ cantam, iluminados tenuamente pela luz dos candeeiros (ver foto 5, na p.6I8). A performance baseia-se no paralelismo e na repetição, levemente diferida no tempo, das sequências do canto. Em seu desenho reiterativo e circular, o canto abriga diferenças internas, que se produzem pela defasagem temporal e pela maneira singular como cada sequência é atualizada por um e por outro, considerada também sua performance corporal.

Esse modo de produzir diferença - de um fundo repetitivo destacam-se pequenas variações - nota-se talvez na maneira como as imagens do filme são compostas. Em uma sequência anterior, ela também emblemática das opções formais em jogo, vemos a imagem de um tronco de mulateiro que, filmado em plano fechado, expõe suas camadas, seus matizes e suas cascas (ver foto 6, na 
p.6I8). A árvore, nos conta o narrador, foi "quem ouviu o canto 'Shuku Shukuwe' da vida eterna”. Diferentemente dos parentes huni kuĩ, que ao escutar o canto não se furtaram a perguntar "para que serve", essa e outras árvores pau-barrigudo, cerejeira, castanheira - e alguns animais - cobra, aranha, barata, siri, caranguejo, camarão - ouviram-no em silêncio: por isso mesmo, até hoje, largam suas cascas e se renovam.

Ora, não seria esse o modo como o fora-de-campo (se é que ainda o podemos chamar assim) se revela no filme? De um fundo homogêneo vão-se destacando, vão-se matizando diferenças: figuras, desenhos, variações de entonação. Nesse caso, o fora-de-campo - mítico, cosmológico - não adentra o campo pelas bordas (em relação com o movimento de câmera). Seus elementos parecem estar lá desde o início, mas só se percebem, sutilmente, quando algo se desprende, quando uma figura oscila e se destaca do fundo da imagem. Essa seria, portanto, uma atualização paradoxal do fora-de-campo que não está fora, mas que, já em cena, circunstancialmente imperceptível, faz-se notar por meio desse descolamento, por meio de um plano que se "descasca", permitindo que as figuras - os eventos, os corpos, os movimentos - se delineiem de um fundo aparentemente homogêneo (por exemplo, a vegetação da floresta). Assim, os quadros fixos de Shuku Shukuwe nos oferecem o recorte e a duração necessários para que possamos acompanhar uma transformação, mínima que seja, que se produz em um fundo estático: o movimento de um inseto, a modulação de uma voz, a variação de luz, uma figura que aparece levemente na penumbra noturna, um corpo que, misturado à folhagem, se move e se dá a ver; a fusão entre um rosto pintado e uma planta (ver foto 7 , na p.6Ig).

Aqui, então, a percepção exigiria uma espécie de pedagogia, da qual o filme faz parte. Em artigo anterior, essa hipótese fora aventada, na abordagem de outro filme huni kuĩ: ao analisar As voltas do kene (2010), ${ }^{30}$ sugerimos ressonâncias entre a forma fílmica e a própria construção formal do kene, grafismos característicos da tecelagem, da cestaria e da pintura corporal, especialidade feminina entre os Huni Kuĩ (Brasil, 20I6b). Na esteira de Els Lagrou, tomamos o kene como imagens-armadilha: elas se valem de uma complexa mas depurada economia formal para capturar o olho e o espírito e conduzi-los em meio à experiência xamânica. A armadilha, nesse caso, opera tanto pelo caráter transformacional das formas (as sutis variações no interior dos padrões, as oscilações entre figura e fundo) quanto por seu caráter sugestivo (a incompletude dos grafismos). "O desenho da cobra contém o mundo", diria Edivaldo, jovem liderança huni kuĩ. "Cada mancha na sua pele pode se abrir e mostrar a porta para novas formas" (Lagrou, 2002: 40).

Ali, ainda em diálogo com Lagrou (2013), nos interessava uma técnica específica chamada umin kene: muito valorizada entre os Huni Kuĩ, ela apresenta certa dificuldade em sua fabricação e percepção, já que, nesse caso, as 


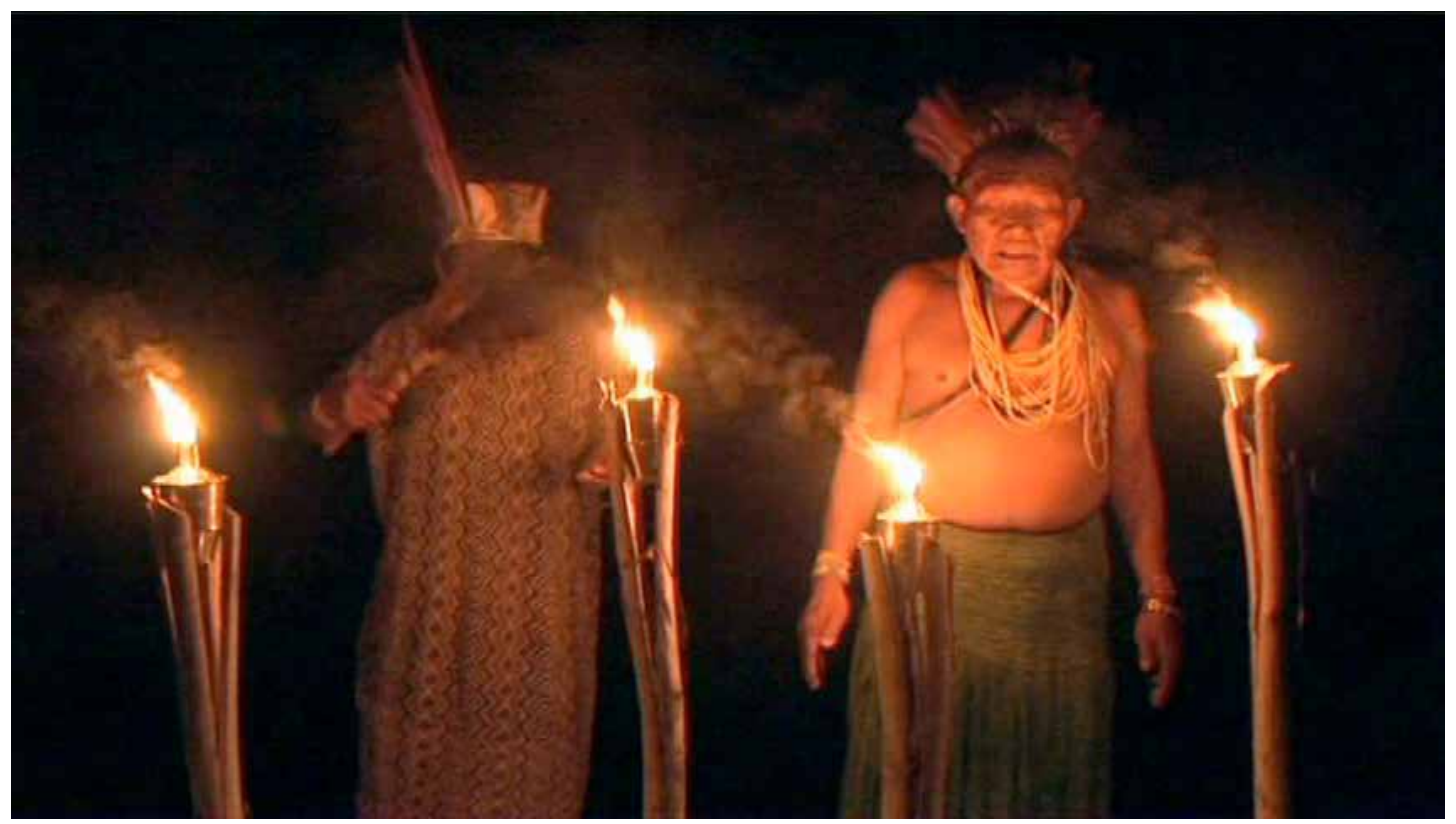

5

O canto: repetição e defasagem

Fonte: Fotograma do filme Shuku Shukuwe

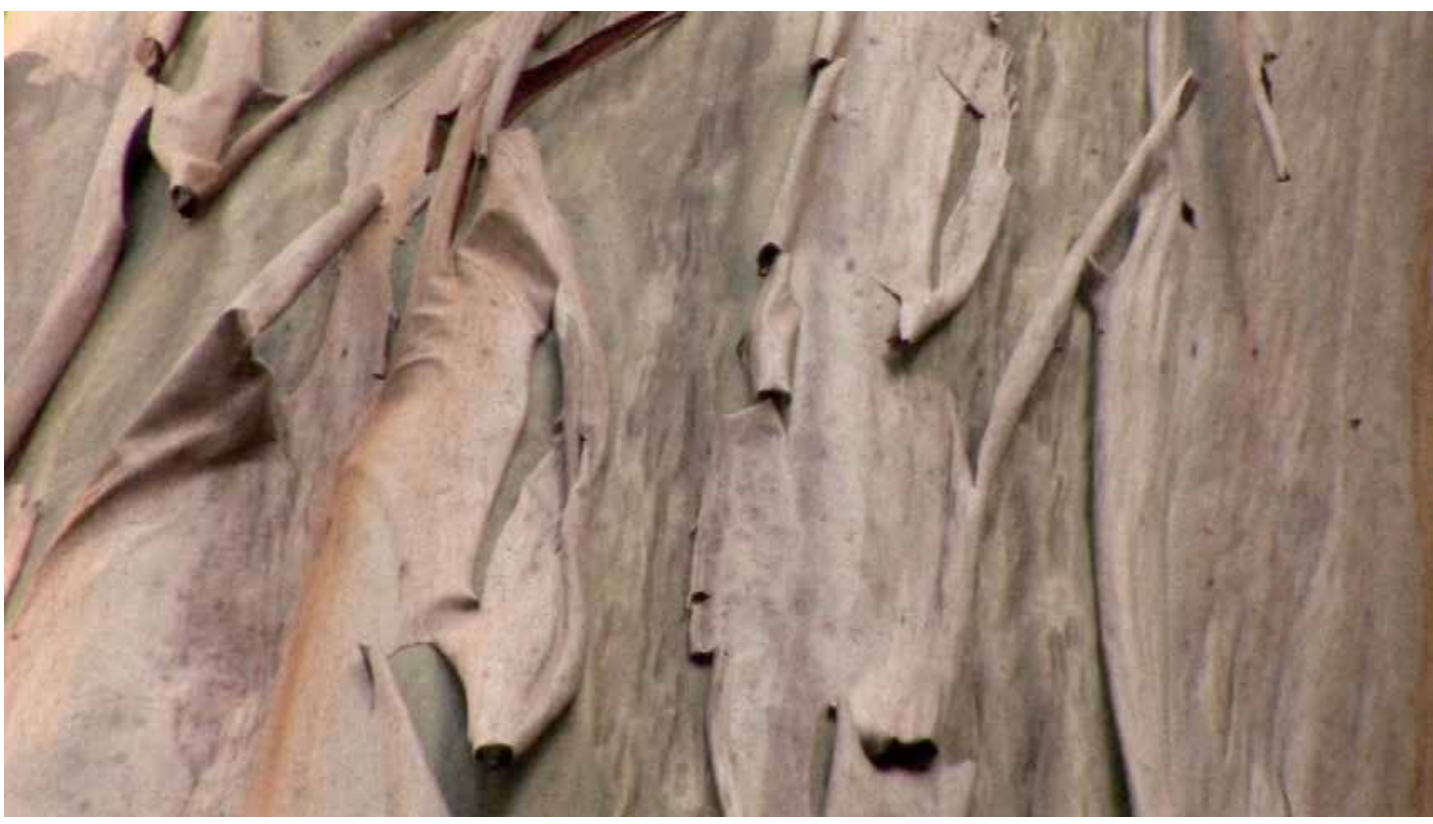



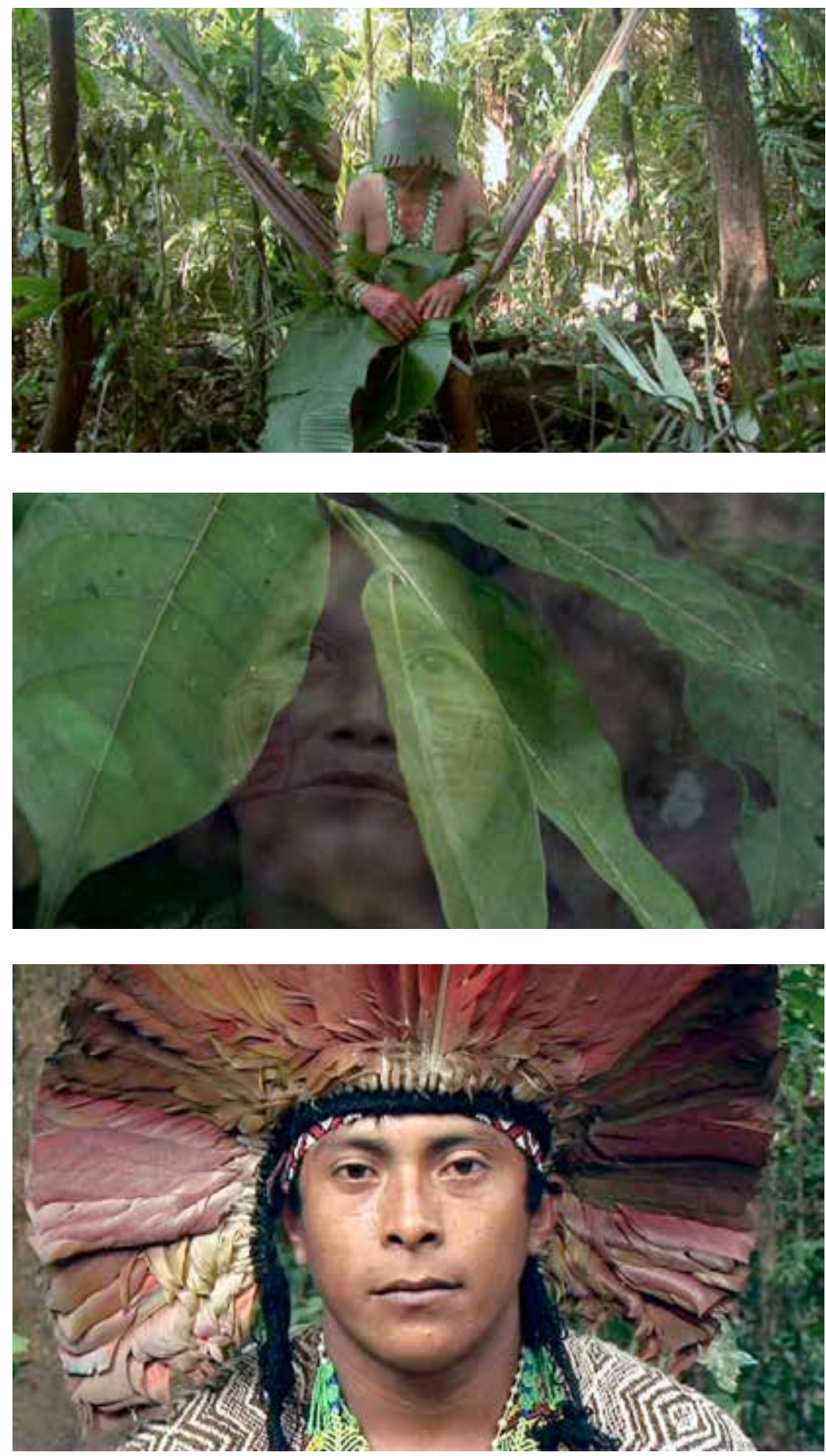
mulheres tecem ou trançam sem utilizar cores contrastantes. A técnica nos ensina, portanto, a ver o que já está visível, mas, cujo ver (uma "percepção imaginativa", de acordo com a autora) precisa ser aprendido pela própria pedagogia do desenho.

Algo semelhante parece ocorrer em Shuku Shukuwe: apreendidas em meio a um processo de transformação, por uma espécie de oscilação do olhar, as figuras se destacam do fundo aparentemente homogêneo, expondo suas diferenças. Elas já estão lá, mas precisam ser reveladas por esse duplo jogo: de um lado, a sutil metamorfose do objeto-imagem; de outro, a percepção que precisa aprender a ver (o que já estava ali visível).

Podemos reter, por fim, uma hipótese: aqui, a maneira como o fora-decampo constitui a imagem tocaria um saber (ou uma cosmologia) cujos elementos, vinculados nesse caso ao xamanismo, não se encontrariam em uma dimensão transcendente, apartada do mundo concreto, visível: eles são imanentes à floresta, ao rio, aos cantos, às relações de socialidade; imanentes a suas transformações e metamorfoses. Vê-los, contudo, depende de um aprendizado, do qual participam essas imagens que - em sua composição e geometria mesmas - armadilham o olhar e conduzem a atenção aos detalhes, às oscilações e aos limiares.

\section{BICICLETAS DE NHANDERU: CONVERSAR, PERAMBULAR}

Lembremos, por fim, o cinema de caminhada e perambulação dos Mbya-Guarani: nesses belos filmes, abertos aos pequenos detalhes e questionamentos do cotidiano, afirma-se o modo de vida na aldeia, não sem o colocar em relação com o entorno das fazendas, das cidades e do turismo. O fora-de-campo permitirá justamente esse duplo e mútuo movimento: de um lado, os personagens deixam a aldeia para viajar pelo entorno (sejam outras aldeias, sejam as fazendas, os municípios vizinhos, os espaços turísticos como as ruínas das Missões Jesuíticas). De outro, esse entorno adentra a vida na aldeia, por meio do comércio miúdo, da festa, do jogo e da bebida, por meio da ameaça invisível dos fazendeiros. Do fora-de-campo, vêm também os signos do universo mítico e espiritual mbya-guarani.

Bicicletas de Nhanderu (20I I), segundo filme feito pelo coletivo, nos tem interessado especialmente pela maneira como trama, à dimensão geopolítica do fora-de-campo, uma outra, cosmológica (Brasil, 20I 2; 20I6b). O espaço exíguo da aldeia de Koenju em São Miguel das Missões se mostra, contudo, aberto, atravessado por relações com o fora. Dedicando-se ao cotidiano e à vida espiritual da aldeia, as cenas do filme constroem-se fortemente pela relação que estabelecem com o fora-de-campo: esse se trama, se traça e se mostra por meio de seus respingos, de suas lascas; por meio das palavras ditas cuidadosamente pelos Mbya-Guarani em suas conversas à beira da fogueira; da errância das crianças pelo entorno; "seja habitado pelos brancos (fazendeiros, tu- 
ristas, comerciantes); seja pelas divindades, o fora-de-campo é coextensivo como que alinhavado - ao cotidiano da aldeia" (Brasil, 20I6b).

Essas "lascas do fora-de-campo" surgem, logo no início do filme, quando um raio cai sobre a árvore próxima, algo que será interpretado como um "susto" provocado por um espírito bravo. Dentro da maloca, a avó Pauliciana conversa sobre o raio e pede um pedaço do galho da árvore, do qual fará colares. Objeto de elaboração e criação, a "lasca" reaparecerá em outros momentos do filme, quando, por exemplo, um dos jovens realizadores mostra para a câmera o colar que ganhara (ver foto 8, nas p.622-623).

Nos filmes mbya-guarani, a trama entre o fora-de-campo (seja aquele do entorno das fazendas e das cidades, seja aquele dos deuses) e a cena segue, em grande medida, o alinhavo das palavras, em uma espécie de mise-en-scène da conversação. Constantemente, os acontecimentos ligados à vida na aldeia são objeto de conversa entre os anciãos e os jovens; entre o karaí e o diretor Ariel Ortega; entre as crianças e a câmera que as acompanha em suas perambulações. Essas conversas são pontuadas por sequências que, elas também, expressam, atenta e sutilmente, a forma como a aldeia "elabora" o que vem de fora; a forma como "espiritualiza" objetos e práticas, seja um pote de gabirobas recém-colhidas, seja uma cerejeira derrubada, seja a festa ou a construção da casa de reza, seja o próprio filme que se expõe em seu processo de feitura.

A palavra mbya-guarani recebe no filme cuidado e espessura à altura de seu papel constitutivo do modo de vida do grupo. Sobre esse aspecto, destacávamos a forma cuidadosa, conscienciosa, precisa como a palavra é ali enunciada. "Como observou pioneiramente Pierre Clastres, parece haver uma preocupação rara em nomear os seres e as coisas segundo sua natureza divina, o que resulta na transmutação linguística do prosaico em uma fala de notável riqueza poética" (Brasil, 20I2). Em entrevista, o diretor Ariel Ortega traduz es se cuidado em termos de realização fílmica, ao chamar atenção para o tempo certo, o momento adequado de enunciação das palavras: "De tardezinha, por exemplo, ou então bem cedo. Esses são os momentos de se conversar, aí as palavras são boas. Por isso existem todas as 'belas palavras'. Por isso também é difícil, porque sentimos quando alguma situação é forçada. Assim, se aquele não é o momento certo, então não é o momento de se filmar" (Carvalho, 20II: I4I-I42).

Ainda que guardem estreita relação com o universo mítico e espiritual dos Mbya-Guarani, no filme as palavras assumem escala prosaica, miúda, fragmentária, e os saberes vão-se pontuando aqui e ali, de maneira mais ou menos alusiva. A palavra é, portanto, ao mesmo tempo profética, poética e errática, tramando-se e alinhavando-se ao tecido do cotidiano. 


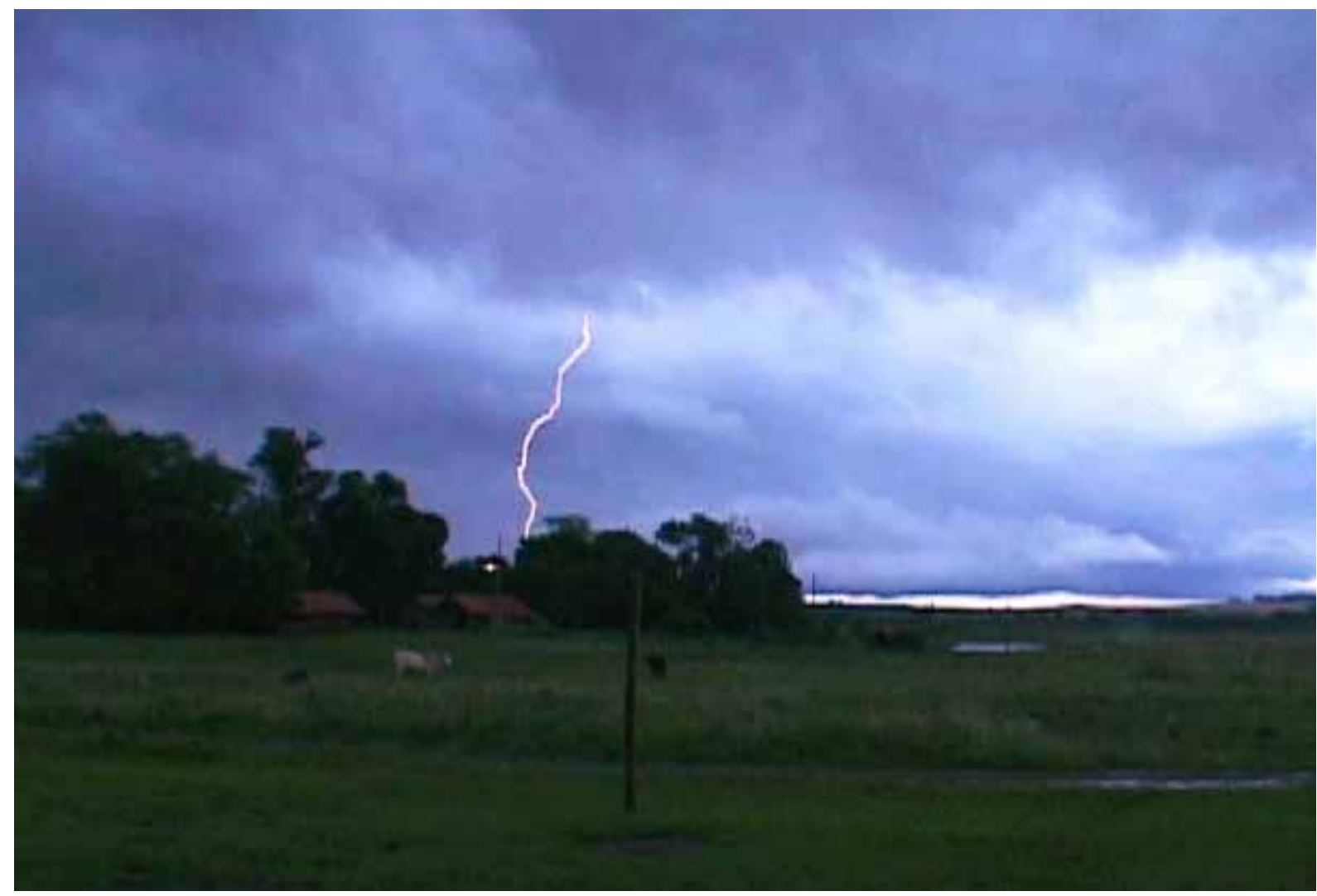



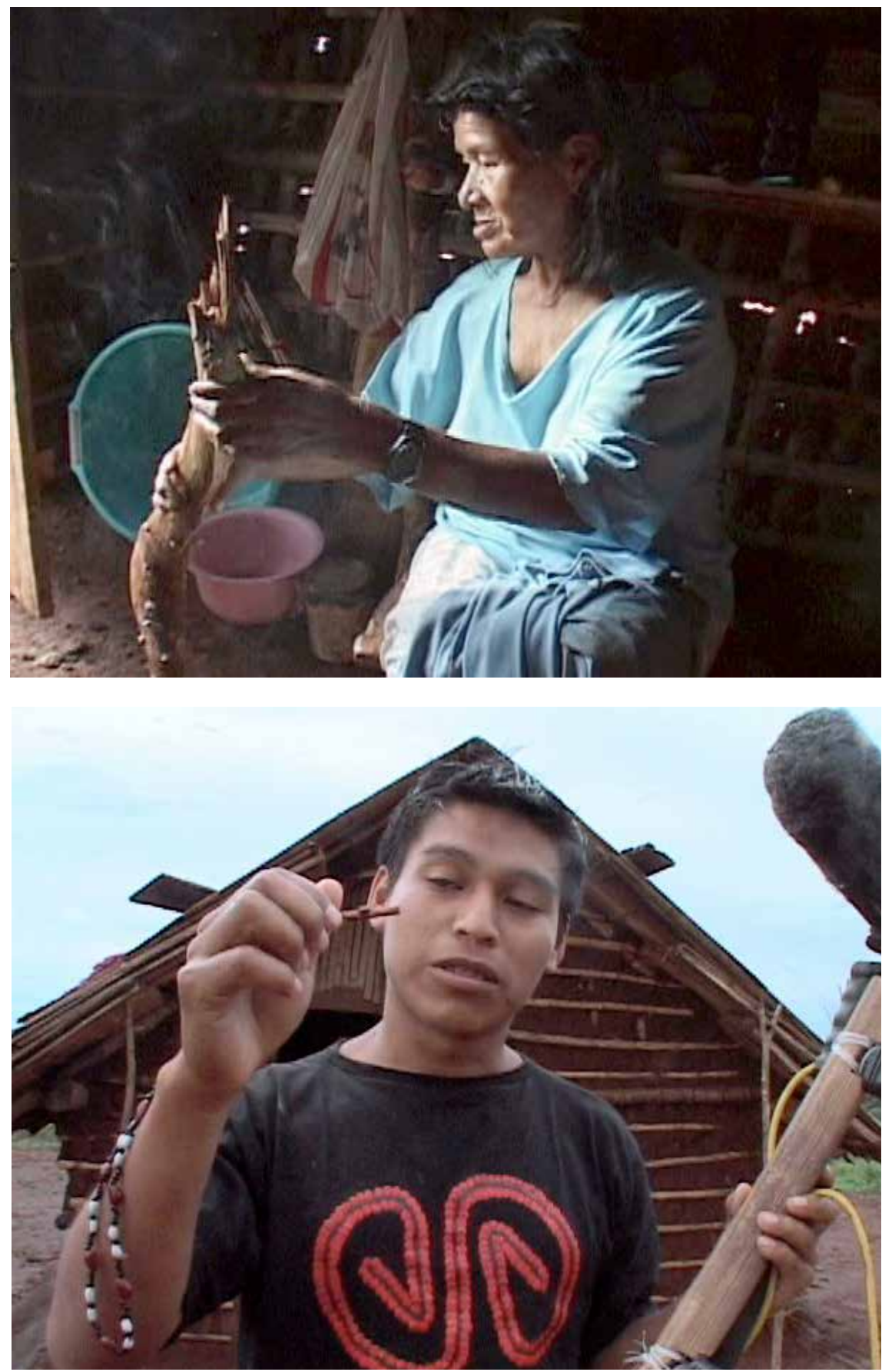

8

Lascas e sua elaboração

Fonte: Fotogramas do filme Bicicletas de Nhanderu 
Esse modo a um só tempo intenso e errático como a palavra se enuncia encontra nas andanças das crianças Neneco e Palermo sua expressão, digamos, "territorial". Trata-se na verdade de movimentos de desterritorialização, por meio dos quais se atravessam as cercas, se escapa dos limites da escola, se passa da mata ao mito, do mito ao pop, desfazendo também os limites da cena - já que muitas vezes o cineasta é convocado para participar da conversa ou é obrigado a intervir delicadamente na caminhada das crianças.

Como vimos, o modo como os filmes operam passagens entre os domínios do visível em campo e do invisível no fora-de-campo varia bastante de um a outro. O espaço que os corpos (assim como suas performances) instauram nos filmes não se reduz a sua dimensão visual apreensível fenomenologicamente pelo enquadramento da câmera, mas abre-se a uma descontinuidade constitutiva e coextensiva à parcela do visível capturada pela operação da filmagem: o seu fora-de-campo cosmológico. Nesses breves momentos dos filmes, o fora-de-campo "relativo" (Deleuze, 2004), aquele que se prolonga por continuidade fenomenológica para fora das bordas do enquadramento, encontra-se numa indistinta zona de vizinhança, de contiguidade com um "alhures mais radical, fora do espaço e do tempo homogêneos" (32). A maneira como os filmes indígenas fazem variar as relações e passagens entre esses domínios descontínuos retorna ao campo teórico do cinema como problema: como pensar o fora-de-campo não apenas como efeito narrativo, mas como condição de existência do próprio gesto de filmar, de habitar o espaço heterogêneo da cena, constituída por uma potente e ativa porção invisível?

Recebido em 05/ıo/20I6 | Aprovado em I6/I I/20I6

André Brasil é professor do Departamento de Comunicação e do Programa de Pós-Graduação em Comunicação (PPGCOM) da UFMG, doutor pela UFRJ, com pós-doutorado na New York University.

Bernard Belisário é doutorando do Programa de Pós-Graduação em Comunicação (PPGCOM) da UFMG. Publicou, entre outros artigos, "Os Itseke e o fora-de-campo no cinema Kuikuro" (2014). 


\section{NOTAS}

I O texto faz parte de nossas pesquisas desenvolvidas com apoio do CNPq (Bolsa PQ) e da Capes (Pós-doutorado no Exterior e Bolsa de Doutorado). Agradecemos aos colegas - alunos e professores - do Grupo de Pesquisa Poéticas da Experiência (CNPq/UFMG) com os quais temos compartilhado várias das inquietações aqui apresentadas.

2 Realizado no segundo semestre de 2016, o curso faz parte do Programa de Formação Transversal em Saberes Tradicionais da UFMG, por meio do qual mestres das culturas indígenas e afrodescendentes ministram disciplinas na graduação.

3 Some-se aos dois outros olhares (anciãos e mulheres) o olhar do próprio Divino na montagem dos filmes.

4 Referimo-nos, por exemplo, ao Kayapo Video Project, desenvolvido por Terence Turner em I990. Antes mesmo, Monica Frota e Renato Pereira já haviam ensinado a dois kaiapós o manejo de uma câmera de vídeo que deixaram na comunidade.

5 "Depois de 30 anos de atividades, porém, reconhecido internacionalmente, [o Vídeo nas Aldeias] está prestes a fechar suas portas, mantendo apenas um endereço virtual [...] O cineasta [Vincent Carelli] conta que as atividades de formação da Vídeo nas Aldeias foram interrompidas 'pelo desmonte da política revolucionária da era Gilberto Gil e do Juca Ferreira no Ministério da Cultura, uma onda de valorização da diversidade cultural brasileira que repercutiu em todos os editais de financiamento das empresas mistas e particulares'” (Outras Palavras, 20I6).

6 Por exemplo, os filmes produzidos pelos Tikmũ'ũn (Maxakali), em projetos coordenados pela etnomusicóloga Rosangela de Tugny, muitos deles em parceria com a Associação Filmes de Quintal; o recente trabalho de formação audiovisual do Observatório da Educação Escolar Indígena na Universidade Federal de Minas Gerais; os projetos de formação do Instituto Catitu; os trabalhos realizados pela Associação Cultural de Realizadores Indígenas do Mato Grosso do Sul (Ascuri); entre muitos outros.

7 “Os índios que agora 'voltam a ser' índios são os índios que reconquistam seu devir-índio, que aceitam redivergir 
da Maioria, que reaprendem aquilo que já não lhes era mais ensinado por seus ancestrais" (Viveiros de Castro, 20I5).

8 Cf. nota 2.

9 No original: "agency, intention, causation, result and transformation".

Io Em texto também dedicado às experiências iniciais do VNA, ao atentar às imagens feitas por Kasiripinã Waiãpi, Evelyn Schuler (I998) aponta ali a valorização da tomada, do plano longo, aberto, "de poucos closes e falas inteiras".Para Diego Madi Dias e André Demarchi (20I3), esse traço teria relações com processos mais amplos de fabricação do corpo e de constituição da pessoa. No juízo das imagens pelos Kaiapó, toma-se como parâmetro o desempenho do cinegrafista, ligado à produção e à performance de um corpo rígido e forte (töjx), o que aproxima o cinema de todo um conjunto de outras atividades (o ataque à casa de maribondos, o pernoite nas águas de um rio, a realização de pequenas queimaduras na pele etc.). A fabricação do corpo - aliada à capacidade de assimilar, por acoplamento, a agência da câmera - será condição de possibilidade da beleza (condição afinal nunca plenamente atingida, sendo o cinema o lugar de imagens "cronicamente imperfeitas"). Nas palavras de Madi Dias (20II), "corpos que fazem imagens que fazem corpos".

I I Ou uma "inteligência corporal", segundo Ingold (2000), retomado por Madi Dias e Demarchi (2013).

I 2 Assim como a imagem fotográfica, a imagem de cinema traria a marca de sua gênese, uma "inscrição referencial" (Dubois, 20I 2: 65), indicial mais do que icônica. Ou, antes, a conhecida definição de André Bazin (2014) da "gênese automática” das imagens fotográfica e cinematográfica.

I3 Temos consciência da complexidade da relação entre fenomenologia e cosmologia, dadas as heranças vindas tanto do campo da filosofia quanto daquele da antropologia. Aqui, os conceitos terão circunscrição cinematográfica: a dimensão fenomenológica se refere aos traços que se fazem sensíveis na imagem, esses que, em grande medida, teriam um estatuto indicial. A dimensão fenomenológica, contudo, não se restringe ao visível, mas àquilo que, visível ou invisível, atravessa e afeta a imagem, para alterá-la. 
Em nossa hipótese, essa dimensão fenomenológica seria alterada ou alargada por uma outra dimensão, no caso, cosmológica. Em linhas gerais, a cosmologia diz respeito às relações de socialidade que também articulam visível e invisível e que constituem o cotidiano do grupo. Essas relações são internas à aldeia, e também se endereçam ao "fora" e às alteridades que dele participam (sejam os brancos, sejam os animais e os espíritos). Aqui, dada a suges tão dos próprios filmes, priorizamos as relações cosmológicas com os povos-espírito, enfatizando as passagens entre mundos ontologicamente distintos.

Vale dizer, por fim, que, em sua feitura e em sua exibição, os filmes participam, eles também, das relações cosmológicas, nelas intervindo e por elas sendo forjados. Uma hipótese que mereceria desenvolvimento é a de que os filmes possam ser tomados, no limite, como espécies de "dispositivos" cosmológicos ou, mais amplamente, "dispositivos" cosmopolíticos.

I4 Emblemático nesse sentido o filme Mulheres xavante sem nome (2009), em que o diretor, Divino Tserewahú, divide a ilha de edição com os anciãos que, diante das imagens, demonstram corporalmente os modos corretos de performar e cantar no ritual.

I5 Lembramos, em outra experiência, dos filmes feitos pelos Tikmũ'ũn (Maxakali) em torno do ritual de iniciação das crianças, contando com a mediação dos espíritos-lagarta. O primeiro filme, realizado na Aldeia Verde, provocou o segundo, realizado na Aldeia Nova do Pradinho. Por fim, Isael Maxakali, diretor o primeiro filme, realizou um terceiro. São eles: Tatakox (2007); Tatakox da Vila Nova (2009) e, mais recentemente, Iniciação dos filhos dos espíritos da terra (20I5).

I6 Referimo-nos, por exemplo, a Pirinop: meu primeiro contato (2007), de Karané Ikpeng e Mari Corrêa. Ali, arquivos de filmes históricos são vistos pelos Ikpeng que, provocados pelas imagens, reencenam a experiência do contato com os brancos.

I7 "Uma imagem é sempre a imagem do outro. Não há imagem sem alteridade" Comolli (2008: I54).

I8 Em alguns autores, o conceito ganha a denominação de extracampo. Optamos aqui por fora-de-campo para enfatizar 
justamente a relação de um "fora" que, invisível e exterior à cena, nela incide.

I9 Dois encontros foram realizados pela Hutukara Associação Yanomami, um em 20I I e outro em 2012.

20 Estamos próximos aqui às formulações de Isabelle Stengers (2005), resumidas em The Cosmopolitical Proposal. No campo da antropologia essa aproximação foi desenvolvida por Renato Sztutman (2013) na palestra Cosmopolíticas transversais: a proposta de Stengers e o mundo ameríndio; e por Tânia Stolze Lima (20I I) em Por uma cartografia do poder e da diferença nas cosmopolíticas ameríndias.

2 I Sobre o estatuto das imagens entre os Yanomami, conferir Viveiros de Castro (2006).

22 A produção executiva de Vincent Carelli e Carlos Fausto consolida a parceria entre o Vídeo nas Aldeias e o projeto Documenta Kuikuro do Museu Nacional/UFRJ. A partir das oficinas de formação ministradas na aldeia de Ipatse desde 2002 foram produzidos também os premiados documentários O dia em que a lua menstruou (2004) e Cheiro de pequi (2006), ambos assinados por Takumã Kuikuro e seus colegas do Coletivo Kuikuro de Cinema.

23 Para o antropólogo Carlos Fausto (20I I: I67), os rituais xinguanos são "dispositivo[s] de transformação coletiva e transitória em itseke".

$24 \mathrm{Na}$ casa, localizada no centro cerimonial da aldeia, encontram-se escondidas as flautas kagutu, cuja visão é interdita às mulheres. Não há tradução para o termo kuakutu na língua kuikuto (Karib). Mehikaku (20I0: I45) acredita tratar-se do termo aruak para a casa das flautas: kuwakuho. O termo é traduzido pelos Kuikuro como "casa dos homens" ou "casa das flautas sagradas", ou "casa dos rituais" (Belisário, 2014b: 89).

25 As onças que atacam os animais de estimação dos Kuikuro durante a madrugada, deixando somente as marcas de sua presença: o desaparecimento de suas presas, suas garras e pegadas no chão.

$26 \mathrm{Na}$ segunda, os tatakox trazem em seus braços as crianças desenterradas para que as mulheres as vejam e chorem. Na terceira, os tatakox levam os meninos tikmũ'ũn para a kukex, separando-os de suas mães, que voltam a chorar. 
27 Por exemplo, Tatakox e Iniciação dos filhos dos espíritos da terra, ambos dirigidos por Isael Maxakali.

28 Como diria Gilles Deleuze (I99 : 99) em sua leitura crítica de Leibniz, são incompossíveis as séries divergentes que pertencem a dois mundos possíveis. A incompossibilidade, nos diz o autor, "é uma correlação original distinta da impossibilidade ou da contradição".

29 Mateus, Agostinho Manduca (org.). Huna Hiwea: o livro vivo. Belo Horizonte: Literaterras/Faculdade de Letras UFMG, 2012.

30 Sobre As voltas do kene, conferir também análise de Marco Antônio Gonçalves e Els Lagrou (2013).

\section{REFERÊNCIAS BIBLIOGRÁFICAS}

Bazin, André. (20I4). Ontologia da imagem fotográfica. In: Bazin, André. O que é o cinema. São Paulo: Cosac Naify.

Belisário, Bernard. (20I6a). Ressonâncias entre cinema, cantos e corpos no filme As hipermulheres. Galaxia, 32, p. 65-79.

Belisário, Bernard. (20I6b). As lagartas-espírito e a invenção do cinema Maxakali. Comunicação Oral na 30 Reunião Brasileira de Antropologia (UFPB) no dia 4 de agosto de 2016.

Belisário, Bernard. (20I4a). Os itseke e o fora-de-campo no cinema kuikuro. Devires, I I (2), p. 98-I 2 I.

Belisário, Bernard. (20I4b). As hipermulheres: cinema e ritual entre mulheres, homens e espíritos. Dissertação de Mestrado. PPGCOM/Universidade Federal de Minas Gerais.

Brasil, André. (20I6a). Rever, retorcer, reverter e retomar as imagens: comunidades de cinema e cosmopolítica. Galáxia, 33 (no prelo).

Brasil, André. (20I6b). Ver por meio do invisível: o cinema como tradução xamânica. Novos Estudos CEBRAP, Io6 (no prelo).

Brasil, André. (2016c). De uma a outra imagem: traduções do visível e do invisível em Curadores da terra-floresta e Xapiri. In: Furtado, Beatriz (org.). Pós-fotografia, pós-cinema e o devir das imagens contemporâneas nas artes (no prelo).

Brasil, André. (2013). O olho do mito: perspectivismo em Histórias de Mawari. Eco-Pós, I5/3, p. 69-89. 
Brasil, André. (20I 2). Bicicletas de Nhanderu: lascas do extracampo. Devires, 9/I, p. 98-I I7.

Caixeta de Queiroz, Ruben. (2008). Cineastas indígenas e pensamento selvagem. Devires, 5/2, p. 98-I25.

Caixeta de Queiroz, Ruben. (2004). Política, estética e ética no Projeto Vídeo nas Aldeias. Catálogo da Mostra Vídeo nas Aldeias - um olhar indígena. Rio de Janeiro: Centro Cultural Banco do Brasil, p. 40-50.

Caixeta de Queiroz, Ruben. (1998). Comunicação intercultural: Vídeo nas aldeias. Geraes - Revista de Comunicação Social, 49, p. 44-49.

Canguçu, Carolina. (20I6). O cinema huni kuĩ no 'tempo da cultura'. Dissertação de Mestrado. PPGCOM/Universidade Federal de Minas Gerais.

Carvalho, Ana (org.). (20I I). Vídeo nas Aldeias 25 anos: I98620I I. Olinda: Vídeo nas Aldeias.

Comolli, Jean-Louis. (2008). Ver e poder: a inocência perdida: cinema, televisão, ficção, documentário. Belo Horizonte: Ed. UFMG.

Deleuze, Gilles. (2004). A imagem-movimento. Lisboa: Assírio \& Alvim.

Deleuze, Gilles. (I99I). A dobra: Leibniz e o barroco. Campinas: Papirus.

Dubois, Philippe. (20I2). O ato fotográfico e outros ensaios. Campinas: Papirus.

Fausto, Carlos. (20I I). No registro da cultura. In: Carvalho, Ana (org.). Vídeo nas Aldeias 25 anos: I986-20 I. Olinda: Vídeo nas Aldeias, p. I60-I68.

Gell, Alfred. (1998). Art and agency: an athropological theory. Oxford: Oxford University Press.

Gonçalves, Marco Antônio \& Lagrou, Els. (2013). Kene Yuxi(n) - As voltas do kene. In: Miglorin, Cezar (org.). Catálogo da Mostra de Cinema e Direitos Humanos. Rio de Janeiro: UFF/Secretaria de Direitos Humanos, p. 66-70.

Ingold, Tim. (2000). The perception of the environment: essays in livelihood, dwelling and skill. Londres: Routledge.

Kopenawa, Davi \& Albert, Bruce. (20I5). A queda do céu: palauras de um xamã yanomami. São Paulo: Companhia das Letras. 
Lagrou, Els. (20I3). Podem os grafismos ameríndios ser considerados quimeras abstratas? Uma reflexão sobre uma arte perspectivista. In: Severi, Carlo \& Lagrou, Els (orgs.). Quimeras em diálogo: grafismo e figuração nas artes indígenas. Rio de Janeiro: 7Letras, p. 67-ıog.

Lagrou, Els. (2002). O que nos diz a arte kaxinawa sobre a relação entre identidade e alteridade? Mana, 8/I, p. 29-62.

Madi Dias, Diego. (20I I). Três paradigmas para pensar o vídeo entre os Kayapó. Catálogo do forumdoc.bh.20 I I, p. 300-328. Madi Dias, Diego \& Demarchi, André. (2013). A imagem cronicamente imperfeita: o corpo e a câmera entre os Mebêngôkre-Kayapó. Espaço Ameríndio, 7/2, p. I47-I7 I .

Mateus, Agostinho Manduca (org.). (20I 2). Huna Hiwea: o livro vivo. Belo Horizonte: Literaterras/Faculdade de Letras UFMG, 284p.

Mehinaku, Mutua. (2010). Tetsualü: pluralismo de línguas e pessoas no Alto Xingu. Dissertação de Mestrado. PPGAS/Museu Nacional/UFRJ.

Morgado, Paula \& Marin, Nadja. (2016). Filmes indígenas no Brasil: trajetória, narrativas e vicissitudes. In: Barbosa, Andrea et al. (orgs.). A experiência da imagem na etnografia. São Paulo: Fapesp/Terceiro Nome.

Outras Palavras. (2016). Vídeo nas Aldeias pode se tornar um endereço virtual. Disponível em: <http://outraspalavras.net/ deolhonosruralistas/2016/I I/I7/video-nas-aldeias-pode-se-tornar-um-endereco-virtual/>. Acesso em 20 nov. 2016.

Schuler, Evelyn. (1998). Pelos olhos de Kasiripinã: revisitando a experiência waiãpi do Vídeo nas Aldeias. Sexta-feira, 2.

Stengers, Isabelle. (2005). The cosmopolitical proposal. In: Latour, Bruno \& Weibel, Peter. (orgs.) Making things public: atmospheres of democracy. Karlsruhe/Cambridge: ZKM/MIT Press.

Stolze Lima, Tânia. (20I I). Por uma cartografia do poder e da diferença nas cosmopolíticas ameríndias. Revista de Antropologia, 54/2, p. 6oI -646 .

Sztutman, Renato. (2013). Cosmopolíticas transversais: a proposta de Stengers e o mundo ameríndio. Palestra no $\mathrm{Mu}$ seu Nacional da Universidade Federal do Rio de Janeiro, em 29 de novembro de 2013 (mimeo). 
Tugny, Rosângela de. (20I I). Escuta e poder na estética tikmũ'ũnmaxakali. Rio de Janeiro: Museu do Índio.

Viveiros de Castro, Eduardo. (2015). O índio em devir. In: Herrero, Marina \& Fernandes, Ulisses (orgs.). Baré: povo do rio. São Paulo: Sesc.

Viveiros de Castro, Eduardo. (2006). A floresta de cristal: notas sobre a ontologia dos espíritos amazônicos. Cadernos de campo, I4/I5, p. 319-338.

Viveiros de Castro, Eduardo. (2002). Perspectivismo e multinaturalismo na América indígena. In: A inconstância da alma selvagem: e outros ensaios de antropologia. São Paulo: Cosac \& Naify, p. 347-399.

Viveiros de Castro, Eduardo. (I99I). Cosmologie. In: Bonte, Pierre \& Izard, Michel (orgs.). Dictionnaire de l'ethnologie et de l'anthropologie. Paris: PUF, p. I78-180.

\section{Filmes}

A iniciação do jovem xavante (Wapté Mnhõnõ). (I999). $56 \mathrm{~min}$. Roteiro e direção: Divino Tserewahú. Aldeia Xavante de Sangradouro (MT). Vídeo nas Aldeias.

As hipermulheres (Itaõ Kuẽgü). (20I I). 80 min. Direção: Takumã Kuikuro, Carlos Fausto e Leonardo Sette. Aldeia Kuikuro de Ipatse (MT). Vídeo nas Aldeias.

As voltas do kene (Kene yuxĩ). (2010). $48 \mathrm{~min}$. Direção: Zezinho Yube. Aldeia Huni Kuĩ de Mibayã (AC). Vídeo nas Aldeias.

Bicicletas de Nhanderu. (20I I). 46 min. Direção: Ariel Ortega. Realização e imagens: Coletivo Mbya-Guarani de Cinema. Aldeia Koenju (RS). Vídeo nas Aldeias.

Cheiro de pequi (Imbé gikegü). (2006). 36 min. [Realização:] Coletivo Kuikuro de Cinema. Aldeia Kuikuro de Ipatse (MT). Vídeo nas Aldeias.

Curadores da terra-floresta (Urihi Haromatimapë). (20I3). 60 min. Direção e fotografia: Morzaniel Iramari Yanomami. Aldeia Watoriki (RR). Hutuka/ISA/UFMG.

Iniciação dos filhos dos espíritos da terra (Kakxop pit hãm koxukxop te yũmũgãhã) (20I5). 40 min. Direção e imagens: Isael Maxakali. Aldeia Verde (MG). 
Mulheres xavante sem nome (Pi'õnhitsi). (2009). 56 min. Imagens [e direção]: Divino Tserewahú e Tiago Campos Torres. Aldeia Xavante de Sangradouro (MT). Vídeo nas Aldeias.

O dia em que a lua menstruou (Nguné elü). (2004). 28 min. [Realização:] Coletivo Kuikuro de Cinema. Aldeia Kuikuro de Ipatse (MT). Vídeo nas Aldeias.

Pïrinop: meu primeiro contato. (2007). 82 min. Direção: Karané Ikpeng e Mari Corrêa. Vídeo nas Aldeias. Aldeia Ikpeng (MT). Vídeo nas Aldeias.

Shuku Shukuwe: a vida é para sempre. (20I2). 43 min. Realização: Agostinho Manduca Mateus Kaxinawá et al. Aldeia Huni Kuĩ São Joaquim Centro de Memória (AC). Leteraterras/UFMG e Associação Filmes de Quintal.

Tatakox. (2007). 22 min. Câmera [e direção]: Isael Maxakali. Aldeia Verde (MG). UFMG.

Tatakox da Vila Nova. (2009). 23 min. Direção: Guigui Maxakali. Aldeia Vila Nova do Pradinho (MG). Vídeo nas Aldeias.

Wai'a Rini: o poder do sonho. (200I). 48 min. Direção, fotografia e roteiro: Divino Tserewahú. Aldeia Xavante de Sangradouro (MT). Vídeo nas Aldeias. 


\section{DESMANCHAR O CINEMA: VARIAÇÕES DO FORA-DE- CAMPO EM FILMES INDÍGENAS}

\begin{abstract}
Resumo
$\mathrm{O}$ artigo se dedica a um conjunto de filmes realizados por cineastas ou coletivos indígenas para demonstrar o modo variável como o fora-de-campo invisível se relaciona ao campo visível, fenomenológico. Trata-se assim de observar como o cinema é constituído pelas forças que atuam de fora para possibilitá-lo, mas também para desfazê-lo (ou, nas palavras de Divino Tserewahú, para “desmanchá-lo”). Tentaremos lidar de modo muito concreto com essa hipótese a partir da análise de sequências de cinco filmes: Urihi Haromatimape: Curadores da terra-floresta (2013); As hipermulheres (20I I); Tatakox da Vila Nova (2009); Shuku Shukuwe: a vida é para sempre (20I2) e Bicicletas de Nhande$r u(20 I$ I).
\end{abstract}

\section{DISSOLVING THE CINEMA: VARIATIONS ON THE OFF-SCREEN SPACE IN INDIGENOUS FILMS}

\begin{abstract}
The article approaches a series of films made by indigenous filmmakers in order to demonstrate the variable modes of the off-screen space (invisible one) in its relation with the screen space (visible, phenomenological one). We observe how this cinema is constituted by agencies that actuate from the outside to make the film possible and also to unfold and to "unmake" it. Analyses of sequences from five films enable the demonstration of this hypothesis in a concrete way: Urihi Haromatimape: Curadores da terra-floresta (2013); The hyperwomen (20I I); Tatakox da Vila Nova (2009); Shuku Shukuwe: a vida é para sempre (20I2) e Bicicletas de Nhanderu (20II).
\end{abstract}

Palavras-chave

Cinema indígena;

Vídeo nas Aldeias;

Fora-de-campo;

Divino Tserewahú;

Performance.

Keywords

Indigenous cinema;

Vídeo nas Aldeias

(Video in the Villages);

Off-screen space;

Divino Tserewahú;

Performance. 